\title{
WHAT DO YOU SEE HERE FROM THIS PICTURE?: QUESTIONING STRATEGIES OF MASTER TEACHERS IN INDONESIAN VOCATIONAL ENGLISH CLASSROOMS
}

\author{
Akhyar Rido \\ (akhyar_rido@teknokrat.ac.id) \\ Universitas Teknokrat Indonesia \\ Jl. Z.A. Pagaralam No. 9-11, Bandar Lampung, lampung, Indonesia
}

\begin{abstract}
This study is an attempt to provide an in-depth understanding of the teaching practices of Indonesian vocational English master teachers, focusing on their use of questioning strategies. Using a qualitative approach, this study was carried out in three vocational schools and involved three selected master teachers. Data were collected through 23 sessions of observations, 40 hours of videorecording, and interviews with 33 students. The findings showed that the master teachers employed an interactive style of teaching and not the monologue norm, where the teachers ask while the students answer the questions. They used closedisplay, open-referential, and follow-up questions. They also nominated specific students to answer questions, asked questions to the entire class, and repeated questions when there was no response. These strategies made the teachers control the lessons, guide the students towards a particular response, and promote interactions. The students were receptive to the strategies as they were keen to contribute when they were given questions and opportunities to speak. The results of this study can be used by various stakeholders to improve classroom interaction and promote interactive learning.
\end{abstract}

Keywords: master teachers; question-planning strategies; question-controlling strategies; interactive learning; Indonesian vocational classrooms

DOI: http://dx.doi.org/10.15639/teflinjournal.v28i2/193-211

The term master teacher is synonymous with excellent teacher (Xuerong, 2012), best teacher (Liando, 2010), expert teacher (Chiang, 2006; Tsui, 2009) and is commonly used to refer the crème de la crème of teaching profession. Individual teachers are awarded as master teachers because of their experiences 
and accomplishments (Rice, 2003) or effectiveness of teaching (Wenglinsky, 2000). They are also chosen among their colleagues for their exceptional characteristics (Barliner, 2005; Bucci 2003; Hamzah, Mohamad, \& Ghorbani, 2008).

In the global context, much research on English master teachers has reported that they promote interactive learning through the use of a large number and various types of questions for different pedagogical purposes. These engage students' involvement and create an interactive learning atmosphere (Chiang, 2006; Ibrahim, Aziz, \& Nambiar, 2013; Li \& Walsh, 2011; Rido, Ibrahim, \& Nambiar, 2014, 2015; Xuerong, 2012). However, studies on English master teachers' questioning strategies, especially in the Indonesian vocational context, are still limited. As such, this study hopes to fill the gap in knowledge that exists concerning the topic in the Indonesian context.

Questioning is very important in the language classroom as it is the tool to interactive learning. The posting of questions during a lesson can also define interpersonal relations between a teacher and the students and indicate the desire to share discourse. By using questions a teacher can identify what knowledge the students already possess and their understanding of specific issues (Walsh, 2011; Xuerong, 2012).

Walsh (2011) and Xuerong (2012) explore the features of second/foreign language (SL/FL) classroom discourse. Both authors focus on teacher talk or communication between teacher and students and include elicitation techniques. According to Walsh (2011), the most common elicitation technique is questioning which is employed to get responses and engage involvement in the classroom.

Walsh (2011) and Xuerong (2012) classify questioning strategies into question-planning and question-controlling strategies. Question-planning strategies refer to types of questions used by teachers in the classrooms. The functions are to elicit response and identify problems, better understand students' knowledge, and invite for further discussions. Question-planning strategies consist of asking open-referential, close-display, rhetorical, and follow-up questions. This also includes asking for supporting data. Meanwhile, questioncontrolling strategies refer to ways or procedures used by teachers to ask questions in the classrooms. The functions are to distribute turn-taking and encourage participation. Question-controlling strategies consist of phrasing the question first and calling on the student, calling on specific students to answer questions, asking questions to entire class, encouraging students to consult their 
classmates before answering questions, encouraging students to initiate questions, moving closer to students when asking questions, repeating question when there is no response, and modifying question when it is not understood.

Questioning strategies are to help mould thinking individuals who can communicate effectively in English in today's workforce (Ihmeideh, Al-Omari, \& Al-Dababneh, 2010; North \& Worth, 2004; Riemer, 2007). These skills are essential to carry out professional practice especially in the international practice of business and engineering (Di Grapello, Kruse, \& Tandon, 2011; Di Grapello, 2013; Hendarman, 2010; Riemer, 2007). Recognising this, such skills are highly emphasised in Indonesian vocational education (Chen, 2009; Directorate of Secondary and Vocational Education, 2012; Ministry of National Education, 2005; Newhouse \& Suryadharma, 2011). Thus, this study aims at investigating the use of questioning strategies by Indonesian vocational English master teachers in the classrooms, the reasons why they use the strategies, and the students' opinions about the strategies. It is important to investigate how teachers ask questions in the classrooms, and to understand why they act the way they do in their classrooms. In addition, students' opinions on the teachers' questioning strategies need to be considered since all decisions about interaction are influenced by them. This study was guided by the following research questions:

1. What questioning strategies are used by Indonesian vocational English master teachers and why do they use the strategies?

2. What are the students' opinions on the questioning strategies used by the master teachers?

\section{METHOD}

This qualitative study aimed to examine the questioning strategies used by three English master teachers (MTs) and was carried out in three vocational schools in Lampung province, Indonesia. Data were collected by visiting the schools and capturing the teaching practices through classroom observations and video recordings. To help supplement this data semi structured interviews with the MTs' students were also conducted.

The participants of this study were three master teachers Mr. W, Miss S, and Miss $\mathrm{N}$ who were selected based on their education, mastery of content subject, accomplishment, and recommendation from school authorities. In this study, the MTs must have a degree in English language education, only taught 
the English subject, achieved teacher certification and attended a master teacher training program, and obtained recommendations from school principals and teacher colleagues. In addition, this study required the MTs to have at least 10 years teaching experience because the literature has established that experience is an important attribute of teacher quality (Ibrahim, Aziz, \& Nambiar, 2013; Jacobs, Gregory, \& Hoppey, 2009; Suharti, 2013). Prior to observation, information given to the MTs included:

a. What the research was about;

b. What would be done during the research study (this includes data collection procedures and role of participants and the researcher);

c. How results would be reported;

d. What the participants would gain from the study;

e. What this study would contribute to the society.

This study also involved 100 students of grade 11 from three different schools. They were students in the classes observed. Miss N's classroom under investigation was grade 11 automotive engineering students, consisting of 33 males and 2 females. She described the students as novice learners from villages around Kalianda City, the capital of South Lampung regency, where English was not widely spoken with limited access to English in the internet, television, radio, and newspaper. Miss S recommended the researchers investigate grade 11 automotive engineering class because she was the home teacher and knew the characteristics of the students very well. The class comprised 24 students who were all boys and categorised as novice learners of English. Meanwhile, Mr. W suggested the researcher observe his grade 11 accounting class, comprising 35 females and six males. He described his students' English proficiency as mixed since some of them were in the intermediate while the others were in the elementary levels. Out of these 100 students, 33 were involved in the focus group interviews.

Data collection was conducted through observations, video-recordings, and interviews with the MTs and the students. Observations were used to look at how questioning strategies were employed by the MTs. The type of observation protocol used in this study is an action protocol which is used to record whether specific behaviors are present or absent during the observational time periods. The number of visits and durations of observations were varied among MTs because when it was seen that patterns did not change so much and each lesson observed became predictable, the observations were stopped. Miss $\mathrm{N}$ 
and Miss S were observed six times while Mr. W was observed 11 times. In total, this study observed 23 formal teaching sessions.

Video recordings were also conducted to discover questioning strategies used by the MTs in the classrooms. A video camera was placed on a removable tripod in the back-corner of the classroom to capture a two-third angle of the classrooms. Each session lasted approximately 90 minutes or 1.5 hours to 180 minutes or 3 hours. Thus, the durations of recordings were varied among the MTs-Miss N 16.5 hours, Miss S 13.5 hours, and Mr. W 10.5 hours. The data from video recordings were, then, transcribed orthographically (broad transcriptions) using transcription conventions by Jefferson (2004) and Simpson, Lee, and Leicher (2002) which were revised to suit the objectives of the current study. Line numbering indicating turn taking was given on the left of the page for easy reference. The results of video recording transcriptions were then referred back to the teachers for verification.

Post-teaching interviews with the MTs were carried out to understand the reasons why the MTs used the questioning strategies in the classrooms. The interviews generally involved asking a series of structured questions; then, probing open-ended questions were asked to obtain in-depth information. The interviews were audio-recorded and transcribed orthographically. The results of the interview transcriptions were referred back to the teachers for verification.

Meanwhile, focus group interviews with 33 students were conducted right after the teaching sessions in the classrooms to elicit their opinions about the use of questioning strategies by the MTs, whether the strategies encourage participation and improve their speaking skills. Each interview session involved three to four students and lasted five to eight minutes. The researcher prepared five structured questions for this interview. However, this was not satisfactory; therefore, an open-ended interview was conducted. Most of the interviews were conducted in Bahasa Indonesia because it was better understood by the students. They were also more comfortable giving their responses in their mother tongue. Some interview sessions, on the other hand, were conducted in English as the students could understand the questions and give their response comfortably. The interviews were also audio-recoded and transcribed orthographically.

After that, the data were analysed using five steps: (1) creating a database (2) open-coding, (3) developing themes, (4) close-coding, and (5) triangulating the data. First, all data gathered from observations and video-recordings were organised and labeled in three separate folders in one data base. Second, the data were studied carefully and unbiasedly. Third, similar strategies were devel- 
oped and the emergent themes were obtained. Fourth, after having the emerging themes, focus-coding was conducted to classify them into sub-categories. Fifth, the final emerging themes were triangulated with the interview transcripts.

\section{FINDINGS AND DISCUSSION}

This study aimed at examining the use of questioning strategies by the MTs and discovering the reasons why the strategies were used. This study also tried to uncover the students' opinions about the use of the strategies. The following sections will present the findings of the study.

\section{Questioning Strategies Used by the Master Teachers}

The results of observations and video-recordings indicate that the MTs' English lessons were dominated by question and answer routines. The MTs used both question-planning and question-controlling strategies in the classrooms.

\section{Question-Planning Strategies}

Question-planning strategies refer to types of questions used by the MTs in the classrooms. In terms of question-planning strategies, the findings show that the MTs asked (1) close-display questions, (2) open-referential questions, and (3) follow-up questions.

\section{CLOSE-DISPLAY QUESTIONS}

Close-display was the most frequent question asked by the MTs. In the following extract, the MTs asked the students yes/no questions and questions with modal.

\section{EXTRACT 1.}

115 T: $\quad$ Is there any difficult word Catur? \{approaching Catur's chair\} (.3) would you write down your difficult 
This extract shows Miss $\mathrm{S}$ and the students discussed a reading text. In lines 115-116, she asked display-questions with a linking verb is and modal would to an individual student in order to know his problem. In line 118, the student gave his response, saying that he had no problem. After that, she approached another student and posed a similar question (lines 119-120). In line 123 , the student gave his response, stating that he found difficult words. It can be seen that after asking this type of question, the MTs normally got short responses from the students. These were actually checking questions which enabled Miss S to identify problems of her students.

The following extract shows how the MTs posed yes/no questions with auxiliary do to the entire class.

\section{EXTRACT 2.}

$\begin{array}{lll}163 & \text { T: } & \begin{array}{l}\text { Ok this was the story for the personal letter ya (.) the } \\ \text { content is about the expression (.) Sarah's expression after } \\ \text { she spends her vacation in Kalianda (.) now (.) do you } \\ \text { have pen pal like this? punya teman seperti ini? }\end{array} \\ 165 & & \begin{array}{l}\text { No } \\ 166\end{array} \\ 167 & \text { SSS: } & \begin{array}{l}\text { From other towns (/) not from other countries but } \\ \text { from other towns maybe (/) punya (/) you don't have (/) } \\ 168\end{array} \\ 169 & \text { T: } & \text { No no }\end{array}$

In extract 2, Miss $\mathrm{N}$ and the students discussed a personal letter which contained past and future events (lines 163-165). After that, in lines 165-166, she asked a display question to the entire class which only needed yes or no answers. In line 167, the students gave their choral response. In lines 168-169, Miss $\mathrm{N}$ asked another yes/no question, indicated by the rising intonation at the end of the structure. Again, in line 170, she got another choral response.

Miss $\mathrm{N}$ mentioned that by asking display questions, the students had more chance giving their response. Similarly, Miss S asked close-display questions because "If I don't ask display question how can I know how far they understand the materials." Meanwhile, Miss W said that "I ask 'do you understand?' 
to make sure if they understand the materials or not and to make students keep the materials in their mind. It is also to encourage them to speak."

As the nature of question is to initiate response, questioning is found to be effective as a means of getting students to speak out which is able to facilitate involvement and foster learning (Ibrahim, Aziz, \& Nambiar, 2013; Xuerong, 2012). More specifically, Athanasiadou (1991), Walsh (2011), and Xuerong (2012) state that display questions are posed to monitor learning and to encourage students to use the target language in the form of verbal responses. Shamossi (2004) adds that the use of display questions encourages learners, especially less proficient students, to get interested.

\section{OPEN-REFERENTIAL QUESTIONS}

Asking open referential questions was the next strategy used by the MTs. The following extract shows how the MTs posed $w h$-form of questions.

\section{EXTRACT 3.}

375

376

377

378
$\mathrm{T}$ :

Ok (.) so this is the sample of curriculum vitae

[distributing handouts] (.3) what do you know about curriculum vitae? (.) why do we need curriculum vitae? \{pointing her handouts\}

In the above extract, Miss $\mathrm{N}$ explained how to write curriculum vitae to the students. After distributing the sample, she asked an open-referential question to the entire class. She asked what (lines 376-377) followed by why (lines 377-378) questions. Here, Miss N wanted to know the students' knowledge of the materials at hand.

The MTs also asked what do you think and how questions in the classroom.

\section{EXTRACT 4.}


Extract 4 reveals that $\mathrm{Mr}$. W discussed a reading text with his students. In lines 143-145, he nominated a specific student to respond to his referential questions. Here, Mr. W wanted the student to critically evaluate her own reading skills.

Mr. W asserted that he regularly asked open-referential questions as he wanted to stimulate critical thinking skills of the students "...it is to know their knowledge and to make them think more critically". Correspondingly, Miss S stated that "I ask open question to know how far they have knowledge about this material."

Athanasiadou (1991), Tsui (2009), and Walsh (2011) claim that referential questions are posed to elicit unknown information and get longer responses; therefore, they are more suitable for more proficient learners (Shamossi, 2004). However, Tsui (2009) argues that the use of referential questions does not necessarily result in longer responses and this happens in this study. In order to overcome this problem, Walsh (2011) suggests teachers get their students to write down their answers before verbalising them, especially while posing referential questions, in order to get better and longer responses.

\section{FOLLOW-UP QUESTIONS}

In the extract below, the MTs asked a series of follow-up questions which comprised $w h$ - questions to a specific student.

\section{EXTRACT 5.}

\begin{tabular}{|c|c|c|}
\hline $\begin{array}{l}118 \\
119\end{array}$ & $\mathrm{~T}:$ & $\begin{array}{l}\text { Ok Lidya (.) this one eee (.) this one ((pointing out the } \\
\text { screen)) ya (.) how to say it in English? }\end{array}$ \\
\hline 120 & $\mathrm{~S}:$ & (silence) \\
\hline 121 & $\mathrm{~T}:$ & A half (.) past (/) \\
\hline 122 & $\mathrm{~S}:$ & Five (.) a half past five \\
\hline 123 & $\mathrm{~T}:$ & A half past five \\
\hline 124 & $\mathrm{~T}:$ & What is he doing? what is he doing? \\
\hline 125 & S: & Emm (.) take a bath \\
\hline 126 & $\mathrm{~T}:$ & Ok (.) take a bath (.) what does it mean? \\
\hline 127 & S: & (inaudible) \\
\hline 128 & $\mathrm{~T}:$ & Ok (.) what does it mean? \{moving closer to the student\} \\
\hline
\end{tabular}


Extract 5 shows that Mr. W and the students discussed daily activity. In lines 118-119, he nominated one student to answer an open referential question. However, there was only a silence (line 120). Since there was no response, in line 121, scaffolding was given by Mr. W "a half (.) past (/)" which was followed by a response from the student (Lidya) "five (.) half past five" (line 122). After that, a follow up display question was posed twice in line 124 . In line 125, the student gave her response. In line 126, another follow up referential-question was asked. However, the student gave an inaudible and unclear response. As there were no clear responses, in line 128, Mr. W switched from one code to another code, repeating the same question in Bahasa Indonesia. Besides eliciting responses, these questions were to check her understanding of the previous learning. Her response was short, comprising some words.

The MTs also asked follow-up questions to the entire class. In the extract below, Miss S combined open-referential and close-display questions.

\section{EXTRACT 6.}

\begin{tabular}{|c|c|c|}
\hline $\begin{array}{l}263 \\
264 \\
265 \\
266\end{array}$ & $\mathrm{~T}$ : & $\begin{array}{l}\text { There are so many similar sounds }(.) \text { there are so many } \\
\text { repeated words ya (.) you can learn from this kind of song }(.) \\
\text { what is similar sounds? what does it mean? similar } \\
\text { sounds }(/)\end{array}$ \\
\hline 67 & SSS: & Suara yang kedengaran sama. \\
\hline 58 & $\mathrm{~T}:$ & Ya (.) how about repeated words? \\
\hline 69 & SSS: & Kata yang diulangi \\
\hline $\begin{array}{l}270 \\
271\end{array}$ & $\mathrm{~T}$ : & $\begin{array}{l}\text { Do you find repeated words in this kind of song? Is there } \\
\text { any repeated words? }\end{array}$ \\
\hline 72 & SSS: & Yes \\
\hline
\end{tabular}

In extract 6 , Miss $\mathrm{S}$ discussed similar sounding words in a song with the students. In lines 265-266, she asked the entire class the concept of similar sounds. In lines 267 , the students give their response. After getting a response, she asked another question (line 268). The students gave their choral response in line 269. Then, she asked more questions in lines 270-271 and, again, the students gave their response in line 272 . These questions were basically checking questions.

Miss S asked follow-up questions to maximise the communicative ability of the students who gave responses as it stimulated them to be more active and 
involved in the classroom activities. Meanwhile, Miss N asserted that "I pose follow up questions because hopefully they voluntarily have conversations with me. I know their ability to speak is limited but still if I talk about favourability things they voluntarily speak up, digging knowledge about something they like."

Follow-up questions are posed to guide students through a process of understanding and to invite them to give more contribution. The use of this strategy promotes oral fluency and stimulates critical thinking skills which can lead to deep learning (Walsh, 2011; Xuerong, 2012). It also promotes negotiation of meaning (Hu, cited in Beaumont \& Chang, 2011; Tuan \& Nguyen, 2010).

\section{Question-Controlling Strategies}

Question-controlling strategies refer to ways or procedures used by the MTs to ask questions in the classrooms. In terms of question-controlling strategies, the findings demonstrate that the MTs (1) nominated student to answer questions, (2) asked questions to the entire class, and (3) asked questions repeatedly.

\section{NOMINATE STUDENTS TO ANSWER QUESTIONS}

In implementing questioning strategies, nominating specific students to answer questions was also a common practice used by the MTs in the classrooms. It is illustrated in the following extract.

\section{EXTRACT 7.}

750

751

752

753

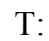

$\mathrm{S}$ :
Ok Mamen (.) Mamen (.) \{approaching a student who sits at the back what is your favorite (.) figure? (.) what is your favourite film?

Power rangers $<$ LAUGHTER $>$

In the above extract, Miss $\mathrm{N}$ discussed reported speech with the students. Miss $\mathrm{N}$ asked one student to create a reported speech based on their question and answer activities. In lines 750-751, Miss $\mathrm{N}$ called on a specific student and started the activities by asking a question about his favourite figure. In lines 751-752, she repaired her question and in line 753, the student gave his answer. 
Nominating students to answer questions, according to Miss N, was to make proficient students help less proficient students. Whereas, Mr. W used this strategy to make inattentive students alert and pay more attention to her as well to ensure that they followed the lesson. In addition, all of the MTs believed that this strategy also gave equal opportunity for each student to practice responding questions in the classroom. In the same vein, Miss S utilized this strategy because she wanted to ensure that each student could cope with the materials at hand. She said "When I asked the entire class, they said they understood. In fact, I knew that many of them still had problems understanding the lesson."

Walsh (2011) believes that nominating students to answer questions can encourage participation and manage contribution as the teacher allots them a turn. This also helps students monitor their own verbal response and allow other students an opportunity to respond to teacher questions. In addition, this strategy signals an interest in hearing what an individual student feels and thinks, indicating that the teacher tries to build interpersonal relations with the students.

\section{ASK QUESTIONS TO THE ENTIRE CLASS}

The findings also show that the MTs frequently posed questions to the entire class to elicit responses and to quickly check students' understanding before moving forward with another material.

\section{EXTRACT 8.}

380 T: Who are they in the picture? \{looking at the handouts

381 SSS: Fire fighter

$382 \quad \mathrm{~T}: \quad$ Ya (.) what are they doing? they are (/) what are they

383 doing? ((acting as if holding a hose)) they are holding a (/)

$384 \quad$ SSS: $\quad$ Holding a hose

This extract shows that Miss S introduced the students to TOEIC-like listening comprehension test and wanted them to look at pictures on the handouts given. In line 380 , she asked a question to the entire class and in line 381 , the students gave a choral response. The next question was posed in lines 382-383 and in line 384 , the students also gave another choral response. These were also 
checking questions and the students' responses indicate that they had understood the materials at hand and Miss S could continue to the next activity.

"I want to make sure they understand my explanation and instruction," Miss S uttered. In addition, Miss N said that the response of the entire class became an indicator of their overall understanding of the lesson. If the response was positive, she would move on to the next discussion; in contrast, if the response was negative, she would repeat her explanations.

Archer \& Hughes (2011) and Xuerong (2012) state that this strategy is used to get verbal response. They add that this strategy is effective to encourage shy students to participate as there is support from their friends.

\section{ASK QUESTIONS REPEATEDLY}

The next strategy, repeating question when there is no response, was used by the MTs when the students did not respond to their questions or gave inaudible response. In general, the MTs firstly posed the question in English, then, repeated the same question in Bahasa Indonesia.

\section{EXTRACT 9.}

$\begin{array}{lll}155 & \text { T: } & \begin{array}{l}\text { Who always cleans this room? who always cleans this } \\ \text { room? } \\ \text { (Inaudible) }\end{array} \\ 156 & \text { SSS: } & \begin{array}{l}\text { Who always cleans this room? siapa yang selalu } \\ \text { membersihkan ruangan ini? }\end{array} \\ 158 & \text { T: } & \text { Usu::p }\end{array}$

In the extract above, Mr. W taught the students questions-responses and focused on pictures on the handouts at hand. In lines 155-156, he asked a question and said it twice. The students gave short, choral, and inaudible responses. The students' weak responses indicate that the students know the answer but are covert learners or do not know the answer. Thus, in lines 158-159, he repeated the same question, first in English, after that, in Bahasa Indonesia "who always clean this room? siapa yang selalu membersihkan ruangan ini?" This time, the students gave a louder choral response in line 160 "Usu::p."

"I repeat questions, three times, four times because they don't respond. I also know they are confused. If I ask once and they can answer my question it's okay," Mr. W uttered. Meanwhile, Miss N stated that she repeated questions several times while asking less proficient students. "Sometimes I am not sure 
whether the students understand my questions or not so I repeat. Usually I repeat question when it comes to the students who are a bit low. These students sit at the back and they usually miss information so I repeat the questions," she said.

Repeating question is a common strategy used by the MTs in the classroom. This strategy is necessary to ensure that the students can hear and understand the question (Archer \& Hughes, 2011). It also provides sufficient time for them before answering the question (Walsh, 2011; Xuerong, 2012).

\section{The Students' Opinions about the Questioning Strategies Used by the Master Teachers}

The study shows that the students gave various comments on questioning strategies used by the MTs in the classrooms. In general, they affirmed that their teachers asked a large number of questions both to individual students and the entire class which made them improve their speaking and critical thinking skills.

\section{Students Improve Their Speaking Skills}

The students think that the questions were posed to encourage them to speak. "Biasanya Miss $\mathrm{N}$ buat pertanyaan... ngelatih kita biasa ngomong Inggris (Miss $\mathrm{N}$ usually asks questions...to make us practice our English)," Harry explained. A similar experience was also shared by Dito. He felt the difference before and after attending the class. Now, he could articulate his ideas more fluently using English. "Dulu cuma tau arti-artinya doang. Sekarang jadi lebih lancar aja. Ya sambil belajar ya kita sembari ningkatin berbicaranya. (In the past I only knew the meaning. Now I can speak fluently. While learning I try to improve my speaking skills)." Meanwhile, Malik uttered that,

Kalau, kalau pandai berbicara itu kurang. Sedikit lebih taulah, pokoknya ada peningkatan lah, walaupun cuma sedikit-sedikit. Guru, guru juga bagus terus temen-temen juga yang lebih pinter juga bisa ngebantu kita. (I'm not fluent in speaking. But I know I feel better, there is a little improvement. My teacher is good and some good friends also help me).

\section{Students Improve Their Critical Thinking Skills}

The students understood that their teachers wanted to check their understanding of the materials. Bambang said that, 
Miss $S$ suka nanya juga, ngecek kita faham apa nggak tentang materi yang diajarkan... hmm..kasih respon gitu. Sejauh ini bisa sih kasih jawaban.. (Miss S likes asking questions to check our understanding towards the materials at hand...to make us give response. So far I can give good response).

Most of the students also stated that their teachers asked wh- questions. "Kalo udah bisa jawab, terus ditanya kenapa kenapa gitu (if we can answer a question, then, she ask why why)," said Dito. Dito's statement is supported by Imran "Kadang Miss N nanya dalem dalem supaya kita berfikir kritis, tapi susah juga jawabnya (she asked deep questions to make us more critical, but it's difficult to answer). Meanwhile, Shinta said that "Mr. W bilang kalo kerja orang suka nanya macem-macem, jadi harus bisa jawab (Mr. W said that in work place people ask a lot of questions; therefore, we have to practice responding to questions)."

Based on the results of interviews, the strategies used by the MTs were positively perceived by the students as they were not reluctant and keen to contribute when they were given questions and opportunity to respond. According to Khmakhien (2012) and Wilhelm and Pei (2008), Asian students are quiet because of the cultural influence. It is a form of respect to their teachers. However, the findings of this study show that the students are enthusiastic to speak in the classrooms. These concur with a study by Pikkert and Foster (1996) which found that Indonesian students are willing to learn. They look passive and shy because of limited English proficiency. In the vocational context, the students will work soon after completing their study; thus, they understood that their teachers wanted them to become thinking questioning individuals who have good communication skills as well.

\section{CONCLUSIONS AND SUGGESTIONS}

To conclude, in terms of question-planning strategies, the MTs asked a large number and various types of questions which comprised close-display, open-referential, and follow-up questions. In terms of question-controlling strategies, they nominated specific student to answer questions, asked questions to the entire class, and repeated questions when there was no response. The questions usually used modals like would, auxiliary $d o$, as well linking verbs as is and are. The MTs also asked questions which were started with what or what do you think, how, and why. In addition, the MTs raised their intonation at the end of their utterance to indicate the formulation of question. From the find- 
ings, it seems that the MTs understood and were aware of the pedagogical goals of the use of the questions, that is, to promote participation and give learning opportunities. Their comments are also in line with Chiang (2006), Ibrahim, Aziz, and Nambiar (2013), Walsh (2011), and Xuerong (2012) who find that master teachers ask questions which generally function to check understanding, elicit response, and promote involvement. It is by asking questions the MTs are able to maintain control of class, especially given that they know the answers to most of the questions they ask (Rido, Ibrahim, \& Nambiar, $2015,2014)$. The students think that the questioning strategies improve their speaking and critical thinking skills. These findings, to some extent, are similar to Chiang (2006), Ibrahim, Aziz, \& Nambiar (2013), Rido, Ibrahim, \& Nambiar $(2014,2015)$.

The findings of this study offer some implications and suggestions for pedagogical considerations within an EFL/ESL vocational setting. The use of questioning strategies in the classrooms made the MTs control the lessons, guide the students towards a particular response, and promote interactions. In other words, the use of questioning strategies opens up space for the students to express their thoughts. This study suggests that teachers should plan their questions to ensure that they match the teachers' pedagogical goals. They should also ask questions which require students to engage in various kinds of verbal responses which help promote students' learning. Next, as not all students are able to respond to all questions, teachers should nominate volunteers because this gives opportunity for other students to respond to teachers' questions. Teachers should also help students formulate questions and make time for students' questions as this facilitates learning and demonstrates a higher level of engagement.

The emergent themes in this study can be used as an initial platform by various stakeholders to improve classroom interaction and promote interactive learning. These findings can contribute to improving the current English language classroom practices in the Indonesian vocational context to prepare Indonesian teachers to nurture young and skilled human capital who have thinking and communication skills. However, some limitations of the study must be noted. The findings of this study cannot be generalised as it is a contextualized case study. It is also important to note that this paper reports on a part of larger research which investigates interactional and pedagogical characteristics of English master teachers in the Indonesian vocational context. 
Rido, Questioning Strategies of Master Teachers 209

\section{REFERENCES}

Archer, A. L., \& Hughes, C. A. (2011). Explicit instruction: Effective and efficient teaching. London, UK: The Guilford Press.

Athanasiadou, A. (1991). The discourse function of questions. Pragmatics: Quarterly Publication of the International Pragmatics Association, 1(1), 107-122.

Barliner, D. C. (2005). The near impossibility of testing for teacher quality. Journal of Teacher Education, 56(3), 205-213.

Beaumont, M., \& Chang, K. S. (2011). Challenging the traditional/ communicative dichotomy. ELT Journal, 65(3), 291-299.

Bucci, T. T. (2003). Researching expert teachers: Who should we study? The Educational Reform, 68(1), 82-88.

Chen, D. (2009). Vocational schooling, labor market outcomes, and college entry (Policy Research Working Paper). Jakarta, Indonesia: World Bank, Human Development Department Sector Department, East Asia and Pacific Region.

Chiang, L.-C. (2006). Voices from the language classroom: A descriptive study of the interactive-decision making of an expert teacher. English Teaching and Learning, 30(4), 23-45.

Di Grapello, E., Kruse, A., \& Tandon, P. (2011). Skills for the labor market: Trends in demands, gaps, and supply. Washington DC, USA: World Bank.

Di Grapello, E. (2013). Role of education and training sector in addressing skill mismatch in Indonesia. In D. Suryadharma, \& G. W. Jones (Eds.). Education in Indonesia (pp. 236-266). Singapore: Institute of Southeast Asian Studies.

Directorate of Secondary and Vocational Education. (2012). Garis-garis besar program pembinaan SMK tahun 2012 [Broad outlines of coaching program for vocational high schools in the year 2012]. Jakarta, Indonesia: Kementerian Pendidikan dan Kebudayaan [Ministry of Education and Culture].

Hamzah, M. S. G., Mohamad, H., \& Ghorbani, M. R. (2008). Excellent teachers' thinking model: Implications for effective teaching. Australian Journal of Teacher Education, 33(4), 11-27.

Hendarman. (2010). Incorporation of employability skills in teaching-learning process within TVE schools. Proceedings of $1^{\text {st }}$ UPI International 
Conference on Technical and Vocational Education (pp. 301-309). Bandung, Indonesia: Universitas Pendidikan Indonesia.

Ibrahim, N., Aziz, A. H. A., \& Nambiar, R. M. K. (2013). What master teachers do: A case study of planning, facilitating, role modeling, and developing materials. International Education Studies. 6(6), 86-94.

Ihmeideh, F. M., Al-Omari, A. A., \& Al-Dababneh, K. A. (2010). Attitudes toward communication skills among students'-teachers' in Jordan public universities. Australian Journal of Teacher Education, 35(4), 1-11.

Jacobs, J., Gregory, A., \& Hoppey, D. (2009). Data literacy: Understanding teachers' data use in a context of accountability and response to intervention. Action in Teacher Education, 31(3), 41-45.

Jefferson, G. (2004). Glossary of transcript with an introduction. In G. H. Lerner (Ed.). Conversation analysis: Studies from the first generation (pp. 13-31). Amsterdam: John Benjamin.

Khmakhien, A. (2012). Demystifying Thai EFL learners' perceptual learning style preferences. 3L: The Southeast Asian Journal of English Language Studies, 18(1), 61-74.

Li, L., \& Walsh, S. (2011). Seeing is believing: Looking at EFL teachers' beliefs through classroom interaction. Classroom Discourse, 2(1), 39-57.

Liando, N. V. F. (2010). Students' vs. teachers' perspectives on best teacher characteristics in EFL classrooms. TEFLIN Journal, 21(2), 118-136.

Ministry of National Education. (2005). Rencana pendidikan nasional jangka panjang 2005-2025 [Long term blueprint of national education in the years 2005-2025]. Jakarta, Indonesia: Ministry of National Education, Republic of Indonesia.

Newhouse, D., \& Suryadharma, D. (2011). The value of vocational education: High school type and labor market outcomes in Indonesia. The World Bank Economic Review, 2(2), 296-322.

North, A. B., \& Worth, W. E. (2004). Trends in selected entry-level technology, interpersonal, and basic communication SCAN skills: 19922002. Journal of Employment Counseling, 41(2), 60-70.

Pikkert, J. J. J., \& Foster, L. (1996). Critical thinking skills among third year Indonesian English students. RELC Journal, 27(2), 56-64.

Rice, J. K. (2003). Teacher quality: Understanding the effectiveness of teacher attributes. Washington D.C., USA: The Economic Policy Institute. 
Rido, A., Ibrahim, N., \& Nambiar, M. K. R. (2014). Investigating EFL master teachers' classroom interaction strategies. Procedia Social and Behavioral Sciences, 118, 420-424.

Rido, A., Ibrahim, N., \& Nambiar, M. K. R. (2015). Interaction strategies of master teachers in Indonesian vocational classroom: A case study. $3 L$ : The Southeast Asian Journal of English Language Studies, 21(3), 85-98.

Riemer, M. J. (2007). Communication skills for the $21^{\text {st }}$ century engineer. Global Journal of Engineering Education, 11(1), 89-100.

Shamossi, N. (2004). The effect of teachers' questioning behavior on EFL classroom interaction: A classroom research study. Reading Matrix, 4(2), 96-104.

Simpson, R. C., Lee, D. Y. W., \& Leicher, S. (2002). MICASE manual. Ann Arbor, MI: English Language Institute, The University of Michigan.

Suharti. (2013). Trends in education in Indonesia. In D. Suryadharma, \& G. W. Jones (Eds.). Education in Indonesia (pp. 15-52). Singapore: Institute of Southeast Asian Studies.

Tsui, A. B. M. (2009). Teaching expertise: Approaches, perspectives, and characteristics. In A. Burns, \& J. C. Richards (Eds.). The Cambridge guide to second language teacher education (pp. 190-197). Cambridge: Cambridge University Press.

Tuan, L. T., \& Nguyen, T. K. N. (2010). Theoretical review on oral interaction in EFL classrooms. Studies in Literature and Language, 1(4), 29-48.

Walsh, S. (2011). Exploring classroom discourse: Language in action. London: Routledge.

Wenglinsky, H. (2000). How teaching matters: Bringing the classroom back into discussions of teacher quality. New Jersey: The Milken Family Foundation and Educational Testing Services.

Wilhelm, K. H., \& Pei, B. C. (2008). University teachers and students' perceptions of ELT methodologies and their effectiveness. Gema Online Journal of Language Studies, 8(2), 79-102.

Xuerong, F. (2012). Excellent English teachers' classroom strategies: A case study of three college English teachers in China. Higher Education Social Sciences, 2(1), 1-7. 